\title{
$O$ cotidiano do homem do século XX e a transformação do diálogo dramático em reflexões monológicas
}

Milca Tscherne*

\begin{abstract}
Resumo: Este artigo apresenta a mudança formal do diálogo dramático a partir das mudanças das relações intersubjetivas operadas no cotidiano, sobretudo, do século XX. Para exemplificá-la, a peça Alguém terá de morrer, do dramaturgo português Luiz Francisco Rebello, que ilustra nos diálogos a falência das relações familiares e na ação o isolamento do eu na solução do suicídio.
\end{abstract}

Palavras-chave: dramaturgia portuguesa; drama moderno; diálogo dramático.

\begin{abstract}
This work presents the aesthetics change of dialogue from the dramatic changes in interpersonal relations operated in daily life, especially the twentieth century. In order to illustrate it, the play Alguém terá de morrer, the dramaturge Portuguese Luiz Francisco Rebello, in the dialogues that illustrates the failure of family relationships and share the isolation of self in the solution of suicide.
\end{abstract}

Keywords: Portuguese dramaturgy; modern drama; dramatic dialogue.

\begin{abstract}
Que desconhecido éramos um para o outro! Quando ele caiu morto, a sua face parecia tão familiar que me perguntei onde eu já teria encontrado aquele homem. Somente no segundo em que fui concebido. Depois disto, nos tornamos, com uma vergonha encoberta, hostis. (O’Neill apud WiLLIAMS, 202, p. 156)
\end{abstract}

Esta epígrafe corresponde a uma fala de uma peça do dramaturgo americano Eugene O’Neill, intitulada de $O$ grande deus Brown (1925). Na cena em que o filho chora a morte de seu pai, há um reconhecimento, não à maneira do teatro antigo, pois em O'Neill não se constata algo novo, mas algo que sempre se soube de quem esteve sempre perto.

Contudo, o que se pode destacar nesse excerto é a sua condição de réplica que não é exatamente dialógica. Ela funciona, à semelhança do que tanto fizera Tchéchov, como receptáculo de uma reflexão monológica.

\footnotetext{
* Doutora em Estudos Literários pela UNESP - Campus de Araraquara e membro pesquisador do Grupo de Pesquisa em Dramaturgia da UNESP.
} 
A preservação da intimidade e a distante relação entre familiares, o desconhecimento recíproco de pessoas que vivem sob o mesmo teto, a comunicação comprometida por uma série de ruídos, a absorção do tempo pelo mundo do trabalho parecem ser algumas causas para a transformação que o diálogo sofreu no último século.

O teatro mimetizou este modelo de diálogo e com ele tematizou a solidão, o isolamento e a incomunicabilidade humana. Deu forma às indiferenças consentidas e presumidas, e as não intencionais também, e a todas as demais dificuldades que pairam entre o falar e o ouvir.

Tal ação e reação formalmente concretizadas pelo diálogo, contudo, foram fortemente exploradas pelo teatro no século $\mathrm{XX}$, pois a variedade formal da produção dramática desse período privilegiou, de maneira bem diversa da do século passado, as tendências de desenvolver a temática do homem só, a tragédia do homem isolado que, embora em meio à multidão do ambiente urbano, não desenvolve laços capazes de lhe dar o valor de si, do outro e da interação nem de situá-lo existencialmente no mundo coletivo.

Em paralelo, no entanto, foi desenvolvida também a ideia do homem com consciência política e com consciência de coletividade. Em ambas as tendências apontam a crise da identidade do sujeito e a luta para se encontrar sentido em si, nas pessoas e nas ações.

$\mathrm{O}$ isolamento, o individualismo e as praxes sociais alavancaram uma mudança formal no drama moderno, pois com essa alteração nas relações intersubjetivas, que beira em alguns casos, à sua própria falência, o diálogo dramático sofreu importantes alterações.

O homem como produto de guerra, de atrocidades e de autoritarismos, como uma mera engrenagem do sistema do mundo do trabalho é representado no século $\mathrm{XX}$ ora como um animal social ora como um homem escasso de sentido, solitário ou alienado. Em ambos os casos, a crise na relação intersubjetiva, já prenunciada no drama no final do século XIX, foi intensificada e a função do diálogo no drama foi redefinida, assim como outros elementos como a própria ambientação.

A dramaturgia do eu, modelo do Teatro Expressionista, o Teatro Épico de Brecht, o Teatro Político de Piscator, entre outros, constituíram, portanto, aquilo que Peter Szondi, teórico húngaro, chamou de tentativas, não mais de salvamento, mas de solução para a crise dramática instaurada no século XX.

Em 1929, um importante livro intitulado O Teatro Político defendeu uma nova tese para a linguagem cênica do drama. Seu autor, Erwin Piscator, foi além do que propusera o 
naturalismo e ampliou o espaço cênico, elevando literalmente o teto do espaço cênico para poder "abranger o mundo" e o conceito de proletariado lúmpen:

[...] Em 1925 eu já não podia mais pensar nas proporções de um aposento apertado com dez homens infelizes; queria pensar nas dimensões de um bairro miserável da metrópole moderna. O conceito de proletariado lúmpen estava em discussão. Eu tinha de ampliar os limites da peça para abranger esse conceito. [...] Assim no todo da peça a minha tendência era, sempre que possível, elevar a dor psíquica do indivíduo até chegar ao geral, ao que há de típico na atualidade, dilatando o espaço estreito para alcançar o mundo. (Apud SZONDI, 2001, p. 128)

A crença em que: o ser social determina o pensamento, e não o contrário, a proposta de trabalhar com argumentos, e não mais com sugestões, a certeza de que o homem é mutável e modificador, a percepção de que o teatro não incorpora um processo e, sim, o narra, entre outras, foram enumeradas e apresentadas por Brecht na sua proposta de criação de um teatro não-aristotélico: o teatro épico.

Assim, não é difícil perceber o suporte teórico e prático que o Teatro Épico deu ao Teatro Político e como se formou uma nova poética que dividiu em formas e linguagens distintas o drama aristotélico (o tradicional) e o não-aristotélico (o épico) no século XX.

A crise da forma dramática nasce justamente do colapso das relações intersubjetivas. Szondi, como teórico do drama alemão do pós-guerra, chama atenção para os monólogos isolados, embutidos numa obra dialógica (2001, p. 50), que aproxima muito mais o drama de uma composição lírica, afastando-se naturalmente da dramática. Tchékov, Ibsen e Beckett compuseram obras dramáticas que exemplificam a crise do drama tradicional. Szondi localiza o início da crise do drama no final do século XIX, quando o seu conteúdo preteriu aquilo que antes prestigiou: o diálogo e a interação humana num presente absoluto (SZONDI, 2001, p. $11)$.

É fundamental registrar que, para Szondi, a forma do drama moderno se define no Renascimento (SZONDI, 2001, p. 13). Ao se suprimirem o prólogo, o epílogo e o coro da composição dramática, o diálogo passou a representar a forma absoluta do novo drama. Diferentemente da tragédia antiga, da peça religiosa medieval ou do teatro barroco e ainda da peça histórica de Shakeaspeare, o drama moderno para Szondi é unicamente aquele que nasce de um despojamento total de composição, de uma redução à relação inter-humana, a fim de o drama definir-se absolutamente como uma forma dialógica, centrada na relação intersubjetiva, cuja única preocupação e ênfase seriam o diálogo.

A seguir, será apresentada uma peça de Luiz Francisco Rebello (1924), dramaturgo português, que articula, justamente, as relações familiares de um cotidiano compassado por valores burgueses. O diálogo expressa bem o desinteresse pelo outro e, como um importante 
pilar da forma dramática que é, denuncia a natureza das relações entre as pessoas da família que a peça protagoniza.

\section{0 cotidiano de uma família burguesa à mesa do jantar em Alguém terá de morrer}

Alguém terá de morrer é peça em três atos revestida por uma mescla de representação realista e fantástica exemplificada pela cena inicial de um momento familiar muito trivial. Num cenário, cuja ambientação caracteriza uma sala burguesa, uma visita inesperada bate à porta. É noite, o agente da morte apresenta-se como qualquer personagem que está em cena, sem caracterização que o identifique como um ser de outra natureza.

A metáfora, sugerida por essa imagem cênica, de algo bater à porta como uma maneira de expressar aquilo que não se procura, mas que chega de forma imperiosa, é cenicamente representada pela personagem do agente da morte, que é a única a desencadear ação dramática na peça. Até a sua chegada, os diálogos e as cenas somente caracterizam o universo social da família e apresentam a situação interna de cada personagem.

São elas: Marta, a mãe e esposa burguesa, só preocupada com eventos sociais e consumismo fútil, caracterizada como mãe displicente; Rui, pai ausente e marido infiel, rico, mas que naquela noite anunciaria a toda família sua falência em função de um empréstimo que não conseguira pagar a seu sócio; Gabriela, a filha jovem que, pelas sugestões da peça, está passando por uma desilusão amorosa; Vítor Manuel, o filho que nunca trabalhou e que guarda em si a certeza de que ocupará um lugar na empresa do pai; e, por último, a irmã de Marta, Augusta, solteirona, mais velha e mais feia do que a irmã, porém a única capaz de perceber como as relações familiares naquela casa estão frágeis.

O primeiro ato ocupa-se da apresentação das personagens e de algumas de suas angústias íntimas, dentre as quais chama atenção o desejo de morrer claramente expresso por duas personagens: por Gabriela, a filha, e por Rui, o pai, que está à beira da ruína financeira.

Antes de a Morte, ou melhor, de um de seus agentes bater à porta, a família se prepara para a última refeição do dia. Na cena do jantar, sabe-se que a mãe está aborrecida porque nem o marido nem a filha quiseram acompanhá-la à ópera; a filha ansiosa aguarda um telefonema; o filho, ausente como de costume; a cunhada angustiada por se jantar cada vez mais tarde naquela casa; e Rui, o pai, tentando articular, por meio de um amigo, um contato com o seu sócio e credor, a fim de lhe conceder um prazo maior para pagamento da dívida. 
Quando o agente da morte bate à porta, a criada Palmira vai atender e anuncia a chegada imprevista de um estranho a seu patrão, que não quer atender por considerar um atrevimento alguém àquela hora chegar sem avisar. A criada deixa a porta encostada e vai avisar aos patrões que seria bom atender por se tratar de um caso de vida ou morte. Sem que ninguém percebesse, a Morte empurra a porta e entra. Já na sala, anuncia-lhes que um deles, naquela noite, teria de morrer. No início ninguém acredita, mas depois, como o telefone pára de funcionar e a porta não pode mais ser aberta, a família começa a se apavorar e a discutir quem seria o escolhido. A Morte anuncia que eles teriam um prazo de três horas, ou seja, até a meia noite daquele dia para anunciar a decisão.

Começa uma curiosa discussão sobre qual seria a melhor vítima, e a família pensa em escolher os que menos faziam diferença: os criados. A Morte, entretanto, reitera que teria de ser um dos cinco membros da família. As irmãs discutem entre si, trocam ofensas, Marta acredita que Augusta, por ser solteira e religiosa, deveria se entregar. Rui, após refletir, propõe que, se o credor chegasse à sua casa, poderia ser ele o escolhido. A Morte interpreta essa idéia como um homicídio e insiste em que a vítima teria de ser um membro da família:

RUI - Daqui a instantes - já não deve tardar muito, com certeza - há-de vir um amigo meu. Bem..., um amigo, é como quem diz... Um dos meus sócios.

O DESCONHECIDO - E que tenho eu com isso?

RUI - Deixe-me acabar! Essa pessoa é, precisamente, aquela a quem eu devo uma avultada quantia.

O DESCONHECIDO - Cujo pagamento tem de ser feito até amanhã. Eu sei.

RUI - Exactamente. E era aqui que eu queria chegar: porque não o leva a ele? Se até à meianoite de hoje alguém terá de morrer, aqui dentro, que lhe importa a si que seja a, b, ou c?... Um morto não tem nome. Os nomes servem apenas para distinguir os vivos uns dos outros.

O DESCONHECIDO (sorrindo) - Não está mal imaginado, não senhor... Mas já agora continue. Estou a gostar de o ouvir...

RUI - Dessa maneira resolviam-se ao mesmo tempo dois problemas. O que o trouxe aqui e...

O DESCONHECIDO (concluindo) - E o seu, não é assim?

RUI - Nem mais. Perante a morte do homem, quem é que vai se lembrar do vencimento do empréstimo? Primeiro que mexam nos papéis e encontrem a escritura, lá se vão pelo menos duas ou três semanas... Depois tem de haver inventários, os herdeiros terão de habilitar-se, hãode seguir-se mil e uma burocracias... Tudo isso demora, seguramente, uns meses largos. E eu, entretanto, terei tempo de dar um jeito à minha vida e arrumar o assunto, com honra para ambas as partes.

O DESCONHECIDO (ironicamente) - Para si também?

RUI - Claro que sim! Nunca pensei em fugir às minhas responsabilidades. É só uma questão de tempo...

O DESCONHECIDO - Não sei se reparou bem naquilo que acaba de me propor...

RUI - E que tem? Não acha perfeitamente legítimo? 
O DESCONHECIDO - Eu conheço mal as vossas leis... Mas creio que o Código Penal chama a isso autoria moral dum crime de homicídio voluntário.

RUI - Que está para aí a dizer?

O DESCONHECIDO - Que o senhor acaba, tranquilamente, de me instigar a cometer um assassinato, para salvar a sua pele e ao mesmo tempo ver-se livre dum credor incómodo...

RUI - O quê?

O DESCONHECIDO - Praticamente, é no que se resume a proposta que me fez...

RUI - Ora adeus! Se vamos a isso, toda a sua existência não tem sido mais do que uma cadeia infinita de assassinatos!

O DESCONHECIDO - Desinteressados. Absolutamente desinteressados e no cumprimento de ordens superiores... Faz uma grande diferença.

RUI - Nesse caso, não aceita minha sugestão?

O DESCONHECIDO - Pois claro que não.

RUI - Mas porquê?

O DESCONHECIDO - Porque é contrária às regras do jogo.

RUI - Para si, então, é um jogo?

O DESCONHECIDO - E para si também. Um jogo de escondidas entre a vida e a morte... (Breve pausa; noutro tom) Mas lembro-lhe que o tempo vai passando. Que já faltou mais para chegarmos à meia-noite. E que até lá, alguém terá de morrer...

RUI - Outra vez! O senhor não sabe dizer outra coisa!

O DESCONHECIDO - Então porque não me ajuda?

RUI - Ajudá-lo?

O DESCONHECIDO - Sim... Talvez pudéssemos resolver este assunto por exclusão das partes...

RUI - Diabos me levem se o entendo!

O DESCONHECIDO - É simples... A sua mulher e a sua cunhada entendem que a escolha não deve incidir sobre elas, não é verdade? O senhor, pelo que lhe diz respeito, também entende o mesmo. Restam portanto os seus filhos...

RUI (Num grito sincero) - Ah, não! Os meus filhos não!

O DESCONHECIDO (rápido e incisivo) - Oferece-se então o senhor?

RUI (hesita. E por fim, lentamente diz) - Também não... (Baixa a cabeça. Um silêncio prolongado. Ouve-se depois bater a porta de entrada. Rui, muito admirado.) Entrou alguém!

O DESCONHECIDO (acena afirmativamente com a cabeça) - O seu filho. (REBELLO, 1999, p. 149-51)

Quando o jovem de 20 anos chega, o pai lhe explica quem é o desconhecido que está na sala: "RUI - Intitula-se enviado - ou agente, não sei bem - da morte, e diz que a sua função é acompanhar os que deixam este mundo na travessia que têm de fazer para outro". (REBELLO, 1999, p. 152)

Vítor Manuel alega que sua vida não tem sentido, que todos os seus dias são iguais, que está farto de sua vida estúpida e se coloca à disposição para acompanhar o desconhecido. Sua mãe, que não estava na sala, quando volta e fica sabendo da decisão do filho, interpreta-a 
como algo muito generoso de sua parte sacrificar-se pela família. Mas o que parecia já se ter resolvido, sofre uma interdição do agente. O jovem indaga a razão de sua recusa e ele lhe responde: "O DESCONHECIDO - Porque ainda é cedo para si. É preciso ter-se amado a vida para se ter o direito de morrer..." (REBELLO, 1999, 156)

Depois de mais discussões, de Marta querer saber quando a tortura chegaria ao fim, de o Desconhecido lhes dar a alternativa de ele mesmo escolher quem iria morrer e de eles recusarem tal escolha, o telefone, que parara de funcionar desde a chegada do Desconhecido, toca. Rui atende e pede que chamem a filha. Ao atender, a menina anima-se por alguns segundos, mas depois cai em desespero novamente. Ninguém na casa sabe a razão de sua tristeza. Todos começam a falar com ela. O Desconhecido alerta a família de que Gabriela nem sequer os está ouvindo e sugere que ela vá descansar no quarto. A menina aceita a sugestão.

Bruscamente, o Desconhecido diz que se vai. Todos se surpreendem e questionam. O rapaz, novamente, pergunta como ficaria a sua situação:

O DESCONHECIDO (já do F.) - A morte não é um prémio de consolação para os que não sabem viver. Aprenda primeiro a amar a vida. Nas horas boas e nas horas más. No sofrimento e na alegria. No desespero e na esperança. E depois sim, terá o direito de morrer. Boa noite. ( $E$ desaparece) (REBELLO, 1999, p. 165)

Depois de sua partida, todos buscam indícios para se convencerem de que aquela visita não acontecera. Desconsideram as reflexões positivas que aqueles momentos de matar ou morrer deveriam ter produzido na família, sobre o modo como se comportavam e se relacionavam uns com os outros; exceto o filho que, deveras, permanece impressionado com algumas alterações estranhas que acompanharam a visita como: o telefone ter parado de funcionar e a porta não poder ser aberta durante o tempo em que o Desconhecido assim o quis.

Para completar a descrença da família nos acontecimentos ruins daquela noite, um amigo de Rui consegue contatar o sócio credor e lhe traz boas notícias por telefone: o prazo para o pagamento da dívida seria de mais um ano. Suas vidas não mudariam mais radicalmente de um dia para o outro como tanto temera. De volta à normalidade, Marta, aliviada, ordena à criada que ponha, finalmente, o jantar.

Todos se preparam para comer quando a criada retorna do quarto de Gabriela com uma notícia que imobiliza a família: 
PALMIRA - Minha senhora... A menina tem a porta do quarto fechada... Estou farta de bater, mas não responde...

(Perante a surpresa e o terror que se estampam no rosto de todas as personagens - que ficaram imóveis, como estátuas, ao F. - e enquanto soam, distantes, misteriosas, implacáveis, num velho relógio fora de cena, as doze badaladas da meia noite, o PANO desce lentamente) (REBELLO, 1999, p. 170)

Alguém terá de morrer apresenta algumas descontinuidades cênicas, sobretudo, nos diálogos, ou seja, no operador das relações intersubjetivas no teatro. É uma peça modelar para se verificar a crise nessas relações, à qual Szondi, teórico húngaro, se refere ao justificar o aparecimento de outros tipos de diálogos no teatro do século XX. Alguém terá de morrer contém uma unidade de tempo e de espaço muito simples. O tempo transcorrido na peça quase não extrapola muito o tempo de um espetáculo ou de uma leitura: 3 horas, ou seja, há quase uma coincidência entre o tempo da ficção e o cronológico real, e o espaço é somente o da sala de uma casa burguesa. Nesse caso, a descontinuidade, ao contrário das múltiplas descontinuidades espaço-temporais apresentadas, por exemplo, na peça Todo o amor é amor de perdição (1991), também de Luiz Francisco Rebello, concentra-se unicamente na ação mais especificamente, nos diálogos.

Szondi, a fim de mostrar as novas formas dramáticas advindas da crise das relações intersubjetivas, postula que um dos pilares da forma dramática clássica era o diálogo por ser o promotor de ação dramática, altamente investido de valor e muito próprio para precipitar eventos num drama.

O teórico apresenta dramaturgos modernos que tiraram do diálogo essa função e que propuseram novas formas para o drama. Cita, por exemplo, os dramas sem ação, os dramas com diálogos absurdos que não são os responsáveis pelas poucas ações que se sucedem, os dramas cujos diálogos se concentram em rememorações e não conduzem a ação no presente, uma vez que o conteúdo das réplicas localiza-se exclusivamente no passado, não tendo muitas vezes relação alguma com o local e com as ações das personagens em cena.

Esses são alguns tratamentos que o diálogo dramático recebeu no século $\mathrm{XX}$ e que levaram Szondi a concluir que - como um dos pilares da forma dramática - ele perdera a sua principal função: promover as relações intersubjetivas entre as personagens, a fim de desencadear ações pertinentes ao conteúdo apresentado pelas réplicas e também pelos outros elementos da cena. Ao mesmo tempo em que assumia outras funções: ser receptáculo de reflexões monológicas, como em Tchekhov; ser meras balizas do verdadeiro fato, em Strindberg; e, ainda, ser intra-subjetivo, como em Ibsen, em cujo teatro o passado é sempre dominante. 
Quando se percebe, em Alguém terá de morrer, que o diálogo inicial do primeiro ato e o diálogo final do terceiro ato são acostamentos que contornam a ação central, conclui-se que a maior parte dos diálogos nessa peça não são unidades de oposição que almejam uma superação, como costuma ocorrer com o diálogo clássico. São falas que são ditas para que as personagens sejam caracterizadas internamente, são quase confissões nas quais se revelam algumas boas razões para que seja cada uma delas a escolhida para a morte.

Em outros casos, eles dialogam entre si, mas não ouvem ou respondem conforme a lógica do conteúdo expresso pelo interlocutor, justamente para representar uma situação de desinteresse pelo outro ou uma situação de introjeção absoluta.

Parece que os diálogos funcionam simplesmente como uma legenda para se entender quem é quem. Não passam de reflexões monológicas acerca deles mesmo, do que pensam, do que gostam, do que esperam do outro. Na parte final, no terceiro ato, há a confirmação de que do modo como se apresentaram no início é como terminam após uma experiência que lhes poderia ter mudado a maneira de viver.

Continuam a olhar somente para si mesmas, a falar sem esperar a resposta do outro, sem sequer considerar essa hipótese como inerente à natureza dialógica, a menos que isso fosse fundamental para a execução do plano momentâneo de cada um, como é o caso de Marta, que sozinha à ópera não queria ir.

O tema da incomunicabilidade ou da indiferença é formalmente elaborado por Rebello através da ausência de diálogos reais numa família pequena - e sem problemas financeiros até aquele momento -, e levado às últimas consequiências: a morte da menina, que ocorre dentro de casa.

A família, desfocada e desatenta, desconhecia por completo as dificuldades da menina, assim como desconhecia que o garoto não se sentia pleno e satisfeito com a vida que tinha. Desconheciam também que o pai, e marido, estava à beira da bancarrota e assim por diante. Parece, ironicamente, que ali não havia um desconhecido apenas, representado pela figura fantástica do agente da morte, mas muitos.

Quando Szondi defende a idéia de que o conteúdo precipita a forma, é justamente um caso como esse que torna evidente o seu raciocínio. Ao representar uma família que não dialoga de fato, o diálogo, aquela estrutura formal e funcional que se conhece, deixa de cumprir a sua função de interação. 
Rebello, para dar forma a um conteúdo dialógico que não repercute numa evolução da ação, explora as potencialidades intra-subjetivas desse meio lingüístico tradicionalmente intersubjetivo, usando-o apenas para dar mostras ao espectador/leitor de como é, internamente, uma personagem.

O diálogo, sem a função comunicativa entre as pessoas, mimetiza muito bem a crise intersubjetiva no drama dos séculos XIX e XX. Em Alguém terá de morrer, o diálogo, genuinamente dramático, só aparece no momento em que a família discute com o Desconhecido as soluções para a tal escolha da noite.

Afora isso, a peça apresenta um dos diálogos típicos do drama moderno - no caso da peça de Rebello, é aquele que não se compromete com a condução da ação. Em algumas peças, esse tipo de diálogo pode trazer certa distensão desnorteadora, como é o caso de $O$ Marinheiro, o drama estático de Fernando Pessoa.

Os diálogos em Alguém terá de morrer, assim como em muitas outras peças de Rebello, não têm um mesmo valor dramático: uns conduzem à ação; outros, não. E é nisto que consiste uma das descontinuidades cênicas da peça.

Outra descontinuidade muito presente no teatro de Rebello, e que certamente é um dos elementos que mais se destacam quando se fala no dramaturgo como renovador da linguagem cênica, é a inserção, no texto e no palco, de personificações de figuras de linguagem que são concretizadas das mais variadas formas. Em Alguém terá de morrer, é a morte, ou melhor, um de seus agentes. Mas não é a figura em si que gera essa descontinuidade; é antes a relação que ela estabelece com as demais personagens. A maneira de todas elas se dirigirem ao sinistro agente, de falarem dele, de o temerem gera distorções na peça, que seria realista se não fosse esse estranho e insólito fato: a natureza figurativa de uma personagem.

A estratégia cênica cíclica da peça corrobora a interpretação do agente como metáfora e amplia a hipótese de leitura ao evidenciar-se o paralelismo de duas cenas especulares: por duas vezes na peça a família se prepara para jantar, a empregada chega com uma notícia e o jantar sofre uma interrupção. A primeira, com a chegada do agente da morte, e a segunda com o comunicado da morte da menina. Ou seja, a estrutura da peça parece atender a duas versões dramáticas para a experiência da perda: uma versão mais figurada e outra mais realista.

No final, a impressão que o texto deixa é a de que o agente era somente uma figura de linguagem que tomou aquela forma para assegurar a compreensão de uma abstração, para provocar uma breve reflexão sobre como a família conduzia suas vidas e nada mais. E que a 
morte da menina, à meia-noite, nada mais fora do que um provável suicídio de uma jovem imatura, sem intervenção nenhuma daquela visita irreal, sobrenatural ou fantástica.

Desse modo, a importante personagem do Desconhecido funciona como uma metáfora e não como algo assustador que, de fato, tomou forma e bateu, literalmente, à porta de Rui e Marta. Tanto é que, ao término, todos se convencem de que aquela visita não acontecera afinal, ninguém escolheu quem deveria morrer. $\mathrm{O}$ caráter fantástico da peça se reforça por dois elementos típicos do gênero: a ambigüidade e o uso impactante da linguagem figurada tomada ao pé da letra.

Essa composição de personagem que aparentemente não desfruta com as outras do mesmo índice de verdade (JAMESON, 1995, p.121), já confere, pelo efeito que causa, a Luiz Francisco Rebello uma linguagem teatral inovadora no seu tempo. A peça, portanto, não apresenta um universo fechado, mas duas naturezas de personagens, aproximando-se do Realismo fantástico, pois há um real que é minuciosamente representado, no qual é inserido o estranho, responsável por gerar dúvidas e ambigüidade:

A junção de dois sistemas de signos relativiza o texto. É o efeito da estilização que estabelece uma distância relativamente à palavra de outrem, contrariamente à imitação, [...] que toma o imitado (o repetido) a sério, tornando-o seu, apropria-se dele, sem o relativizar. (KRISTEVA, 1974, p. 72)

A estilização que Rebello faz da morte na peça e a junção de dois sistemas de signos um mais realista e um mais fantástico - relativizam o clichê da morte que bate à porta, a ponto de distanciá-la de si mesma e fazê-la passar a ter, no final da peça, outro significado, que é mais o da reflexão sobre a vida e a morte e de como um imprevisto pode alterar toda uma rotina, do que o de acentuar o caráter estranho dos dois universos. O Desconhecido comporta-se, entre as personagens, como o elemento dramatizador e não como um agente que, de fato, tiraria a vida de um deles; tanto é que nem eles mesmos acreditam na existência do agente após a sua partida.

Se se tratasse de uma narrativa, o narrador ideal para provocar esse efeito de dúvida seria o de primeira pessoa. Num texto dramático, isso se processa pelos diálogos ou pela caracterização da personagem. Uma personagem desperta dúvidas sobre a veracidade do que fala quando é caracterizada, por exemplo, como perturbada, desequilibrada, ou ainda, se estiver embriagada.

Na peça de Rebello, parece que é o fantástico presente na caracterização do agente da morte que faz a família entrar num consenso sobre a irrealidade daquela visita. Essa 
ambigüidade sobre a materialidade do Desconhecido provoca uma dupla possibilidade de interpretá-lo, ora como uma personagem com identidade própria, ora como um alerta de consciência que todos na casa precisavam receber.

José Régio na peça $O$ meu caso, publicada em 1957, apresenta também uma personagem chamada simplesmente $\mathrm{O}$ Desconhecido, um intruso cuja função assemelha-se à da personagem homônima de Rebello, embora com uma participação metateatral, que inexiste em Alguém terá de morrer. Ambas se identificam pela função dramática que desempenham:

Ao assumir o espetáculo, este elemento "excêntrico", "o desconhecido", provoca o alargamento do horizonte cotidiano através de uma visão mais ampla. Ele vai mostrar que o homem não é humanamente perfeito, que nele a sombra e a luz, o grotesco e sublime existem um ao lado do outro. (SANTOS, 1979, p. 71)

A descontinuidade cênica da peça é percebida, portanto, sobretudo nos diálogos e nas personagens que, ao contrário do que ocorre no teatro clássico, não desfrutam do mesmo valor, produzindo assim um efeito descontínuo, tanto no enredo - que é rompido por elementos que escapam à base realista da peça - quanto nas duas possibilidades de interpretação, contrárias uma à outra: uma é a da existência da figura concreta do Desconhecido; a outra é a do Desconhecido como figuração humana da voz da consciência.

\section{0 suicídio burguês e a ação reflexiva no drama}

O suicídio aparece em pelo menos três peças de Rebello: Alguém terá de morrer, $E$ urgente o amor e Todo o amor é amor de perdição. O efeito que ele causa no drama é um pouco diferente de uma morte em que o agente e o paciente são diferentes. Se sonoramente fosse feita uma comparação, o suicídio seria o silêncio e um assassinato o grito. No drama, o suicídio produz uma inação, pois quem agia, decidiu agir de forma absoluta contra si mesmo, de modo a não agir mais. Este tipo de morte, de ação parece ser, no teatro de Rebello, uma estratégia formal de descontinuidade cênica.

A expectativa na evolução da ação nesta última peça analisada, Alguém terá de morrer, por exemplo, era de que o Desconhecido levasse algum membro da família por meio de uma intervenção externa, a escolha de um deles feita por eles mesmos.

No entanto, a personagem que se manteve isolada em seus problemas e não dividiu os espaços coletivos da sala e da sala de jantar e que não participou das discussões é quem foi a escolhida. Mas nesta escolha há um paradoxo, pois há uma clara sugestão de suicídio e, portanto, de uma escolha que não fora da família nem do Desconhecido, mas da própria 
menina que nada sabia acerca do prazo dado pela estranha visita para que uma morte acontecesse ali antes da meia-noite. Isto enfraquece toda a ação dramática, no sentido de ação real do Desconhecido, ao qual é conferida, ao fim, uma função mais de mensageiro do que de ceifador, pelo menos nos moldes em que se apresentara.

Como o suicídio é um ato realizado por um indivíduo contra ele mesmo, cria uma ruptura na tensão dramática por não haver mais conflitos a serem superados. Não há a busca pela retratação de um erro ou de um culpado, a cobrança de nada externo pelas demais personagens; há, sim, um esfriamento da ação e uma condução à harmonia ou a um fim de reflexão trágico-existencial.

Em Romeu e Julieta, por exemplo, após a descoberta do suicídio de Julieta, um dos guardas dá uma série de orientações e, ao ficarem sabendo da tragédia, ambas as famílias se harmonizam, reconhecem que vitimaram os seus filhos e prometem construir estátuas de ouro do casal, ou seja, segue ao suicídio uma desaceleração dramática rumo à harmonia, ao contrário do que se poderia esperar:

$1^{\circ}$ GUARDA: [...] Visão mais lamentável! Aqui jaz o conde assassinado. - E Julieta, sangrando! Ainda quente, recém-morta, essa que esteve aqui sepultada estes últimos dois dias. Vão, contem ao Príncipe -, corram à casa dos Capuleto -, acordem os Montéquio -, e outros de vocês vasculhem este lugar. (Shakespeare, 2009, p. 148)

$$
[\ldots]
$$

CAPULETO: Ah, irmão Montéquio, dê-me sua mão. Este é o legado de minha filha, e nada mais tenho a oferecer.

MONTÉQUIO: Mas eu posso oferecer-lhe mais: mandarei construir uma estátua de Julieta em ouro maciço. Enquanto Verona for o nome de nossa cidade, nenhuma imagem terá mais valor quanto a de Julieta, digna e fiel.

CAPULETO: Pois a estátua de Romeu, também em ouro, estará ao lado da de sua esposa. Pobres vítimas de nossa inimizade! (SHAKESPEARE, 2009, p. 154)

É interessante pensar no suicídio da menina da peça de Rebello como um elemento formal e não exatamente dramático porque sequer se sabe o porquê desse ato. A questão central desse drama é o conflito que a discussão sobre a escolha de quem morreria produz naquela família individualista, e não um conflito específico de uma personagem.

Neste caso, o suicídio representa uma ruptura das relações - tal como o diálogo, que não se legitima enquanto troca intersubjetiva. Ele ali se manifestou como a intensificação máxima do isolamento da vida em família, da negação da relação com a vida e da impossibilidade de se superar algum obstáculo interpretado como demasiado grande.

A tensão da peça se mantém durante o tempo em que se discute sobre quem irá morrer. A escolha entre as opções da casa gera todos os conflitos menores de Alguém terá de morrer. Eles todos teriam de condenar alguém à morte e nisso há ação. No entanto, a escolha deliberada não é feita e o oposto acontece: alguém se escolhe, a tensão se esvai e o pano cai, 
ou seja, o suicídio é a escolha oposta ao exercício que a família teria de fazer: escolher, dentre todos os que queriam viver, um para morrer. Camus diz que "o oposto do suicídio é, precisamente, o homem que é condenado à morte" (Apud WILLIAMS, 2002, p. 231), ou seja, acontece na peça o oposto da proposta e da expectativa criadas pelo Desconhecido.

Nesta família burguesa, há o nítido retrato de que o viver não é mais importante do que o não morrer, não ser escolhido para deixar de existir. No meio social regido pelas aparências, a escolha só era bem-vinda quando os privilegiava de algum modo. Ser escolhido para desaparecer era uma afronta, embora nenhum dos integrantes da família valorizasse, de fato, a vida.

Ninguém ali se compromete como um mártir a assumir para si esse fim e livrar os demais. Pelo contrário, uns indicam os outros e o conflito dramático reside nesse jogo.

Lembrando da definição de Brunetière sobre os tipos de conflito, poder-se-ia enquadrar o suicídio como uma superação de conflito por ser uma escolha, um ato de exercício da liberdade do sujeito e, portanto, de natureza dramática; e a condenação à morte como a expressão de uma vontade alheia e não do sujeito e, portanto, um conflito insuperável, de caráter tragicamente imposto.

No entanto, o suicídio assume um valor trágico não só nas tragédias clássicas, como nas burguesas também, por ser uma ação absolutamente extrema que impede qualquer outra decisão ou revisão da solução encontrada. Se "para qualquer homem, a sua própria condição particular é absoluta" (WILLIAMS, 2002, p.235), ele fatalmente será refém de seu estado de espírito e suas escolhas dependerão das condições em que elas se lhe imporão e uma das condições muito comuns nas tragédias modernas é o desespero.

Nesse caso, há de se contestar o pretenso exercício de liberdade do suicido e até compará-lo com o destino do herói trágico. Há certamente mais liberdade no herói trágico, cujo fim é a sabida e esperada morte, mas que ele recebe por desafiar o destino, do que naquele que sucumbe a um desespero circunstancial e obedece a um comando que o desvia de encontrar com clareza uma superação que seja, ao menos, reversível. Esse desespero parece esbarrar-se no tema já citado da tragédia romântica, que é o do desamparo, ou seja, da impossibilidade de o sujeito se sentir acolhido pelo mundo:

O desespero real significa a morte, o túmulo ou o abismo. Se o desespero impele ao discurso ou à razão e, sobretudo, se resulta no ato de escrever, a fraternidade está estabelecida, os objetos naturais são justificados, o amor nasce. (Camus apud WILLIAMS, 2002, p. 230)

Não sem razão, a tragédia clássica de Eurípides, Medéia, por exemplo, ou as tragédias burguesas como Fatal curiosity (1736), de Lilllo, e $O$ mal-entendido (1944), de Camus, 
trazem como solução do conflito não somente a morte, como sempre se espera de uma tragédia, mas o suicídio.

A morte pelo suicídio, no drama, é talvez o primeiro elemento que nega a relação intersubjetiva. A morte, nas tragédias clássicas, tem seu espaço reservado para o final. No drama ou na tragédia burguesa nem sempre. No início, no meio ou no fim, o efeito que o suicídio causa, no drama, é o de ser uma das muitas formas de expressar a incomunicabilidade, o isolamento, a ausência do sentido e os demais desencontros dos afetos, das idéias e da comunicação muito bem representados em $O$ mal entendido que, segundo Williams, se assemelha de forma notável à peça de Lillo, Fatal curiosity, que

Tem por base, ao que se diz, um assassinato real ocorrido em Cornwall. Ali um pai e uma mãe matam um estranho que é, na verdade, o seu filho, por um escrínio de jóias que ele trouxera da Índia e deixara a seus cuidados. Quando a identidade do filho é revelada, o pai mata a esposa e a si mesmo. (2002, p. 234)

À semelhança disso, a peça de Camus trata de uma longa ausência de um homem que retorna à estalagem mantida por sua mãe e irmã. Como queria ter o prazer do reconhecimento, o homem não se identifica. No entanto, é morto por ambas, prática rotineira por elas adotada contra os hóspedes solitários e com dinheiro.

O dinheiro nesses dramas burgueses é o deflagrador da tragédia, e o modo como consegui-lo é o elemento dramatizador de toda a ação. Talvez pela inconsistência do objetivo, o dinheiro, e por não haver nenhum grande ideal sustentando esse desejo de possuí-lo, quando se erra o alvo o suicídio surge como solução, pois tanto a vida do outro quanto a própria parecem valer menos do que o status que o dinheiro pode dar:

CALÍGULA: É verdade que se eu não respeito [a vida humana] mais do que respeito a minha própria vida. E, se o ato de matar me vem com facilidade, é porque morrer não me é difícil. (Camus apud WILLIAMS, 2002, p. 232)

A dúvida que persiste, quanto à tragicidade dos desfechos com morte no teatro, é sobre o que seria mais trágico: se as mortes dos grandes e corajosos heróis por grandes causas e honrosas batalhas, ou a morte sem causa suficientemente justificável, pelo menos na aparência, do herói burguês - o homem comum das ruas e do cotidiano urbano.

\section{Referências}

JAMESON, F. As marcas do visível. Rio de Janeiro: Graal, 1995.

KRISTEVA. Julia. Introdução à semanálise. São Paulo: Perspectiva, 1974. 
REBELLO, Luiz Francisco. Alguém terá de morrer. In: Todo o teatro. Lisboa: Imprensa Nacional Casa da Moeda, 1999. p. 109-155.

RÉGIO, José. O meu caso. In: Três peças em um acto. Lisboa: Portugália, 1969.

SANTOS, Maria Antonia dos. A. Teatro no século XX em Portugal. Rio de Janeiro: Olímpica, 1979.

SARRAZAC, Jean-Pierre. Théâtres intimes. Paris: Actes Sud, 1989.

SHAKESPEARE, William. Romeu e Julieta. Porto Alegre: L \& PM, 2009.

SZONDI, Peter. Teoria do drama moderno [1880 - 1950]. São Paulo: Cosac \& Naify, 2001.

Teoria do drama burguês. São Paulo: Cosac Naify, 2004.

WILLIAMS, Raymond. Tragédia Moderna. São Paulo: Cosac \& Naif, 2002. 